\title{
Engaging Students' Information Literacy Ability On The 1945 Constitution Toward Android (Gejog Lesung) Based E-Learning Media
}

\author{
Isna Sari Rukmana ${ }^{1 *}$, Marzuki², Kharisma Fenditasari ${ }^{3}$ \\ 1,3, Postgraduate student, Yogyakarta State University, Yogyakarta, Indonesia \\ ${ }^{2}$ Doctor, associate professor, department of civic education, Yogyakarta State University, Yogyakarta, Indonesia \\ e-mail: Isnasari.2018@student.uny.ac.id, Marzuki@uny.ac.id, and kharismafenditasari.2018@student.uny.ac.id
}

\begin{abstract}
This study aims to analyze students' information literacy ability enhancement using android (gejog lesung) based e-learning media on the 1945 constitution. The method used in this study was a quasi-experimental method. This research used 35 students as subjects. The test used in this study aims to collect data consisting of pretest and posttest information literacy questions with HOTs criteria for information literacy skills and consisting of ten multiple-choice questions according to high order thinking skills criteria then checked for the Content Validity Index. Data analysis is using a t-test. The result of this study is gejog lesung it is able to improve students' information literacy ability on the 1945 constitution of 1,4 in the high category. So, it can be concluded that engaging students' ability of information literacy on the 1945 constitution toward android (gejog lesung) based e-learning media has a great influence on improving students' information literacy ability.
\end{abstract}

Keyword: Android, Gejog lesung, literacy information

\section{Introduction}

One of important factors to advance a nation is human resources. Realizing reliable and quality human resources, there needs efforts to improve the education quality in Indonesia by increasing skills appropriated with 21 st century demands (Insyasiska et al., 2015; Rohmawati et al., 2018; Romero et al., 2015). The appropriate skills in the 21st century can be divided into three parts, there are: life and career skills; learning and innovation skills; technology and information media skills. Life and career skills include; flexibility and adaptability; initiative and self-regulation; social and cultural interaction; productivity and accountability; and leadership and responsibility; besides that, learning and innovating skills include: critical thinking and problem solving; communication and collaboration; creativity and innovation. Technology and information media skills include information literacy; media literacy and ICT literacy; science literacy; economic literacy; technology literacy; visual literacy (multicultural literacy) to expand though of global awareness (Hong et al., 2020; Olszewski \& Crompton, 2020; Yu et al., 2017). One of the skills should be developed in 21st century is the ability of information literacy (Dolničar et al., 2020; van Laar et al., 2017). However, the information literacy level capabilities possessed in Indonesia is still relatively low. This can be proven by the Indonesian society being an alliterate society. To add, schooling still lacks opportunities for literacy traditions to students, besides that, the teaching model is still a teacher center so students are just (Listiana, 2018; Setiawan et al., 2017; Suyono et al., 2017). Even though the information literacy ability is an important thing to be cultivated to avoid explanations that are not necessarily true or false. Especially in civic education learning that teaches about morals values (Dianti, 2014; Setiwan, 2013). Therefore, the integration between information literacy ability skills and civic education learning needs to solve.

The 21st century development which demands quality in all endeavors and work of human being want to changes in all sectors including educational innovation. Not only

\footnotetext{
${ }^{*}$ Corresponding author.
}

Received 15 April 2020; Accepted 16 August 2020; Available online 01 September 2020 (C) 2020 JPI. All Rights Reserved 
conventional learning and teacher center learning, but also students as the education target are also required to literate in sophisticated technology and actively involved in empowering their success (Geisinger, 2016; Siddiq et al., 2017). In addition, the 4th world revolution is currently demanding a digital information-based lifestyle in all human being sectors (Caruso, 2018; Huynh et al., 2020). One of them is education sector. In this case, the 4.0 industrial revolution demands that education have to prepare quality graduates, globally competition, master the technology and communication, big data, and cloud computing development (Alam et al., 2020; Tsybulsky \& Levin, 2019). So that, the human resources are committed and flexible in manufacturing or other fields with good quality. One of them is the technology use in educational media development. However, the development of technology-based educational media is still underused because of many reasons. Whereas learning media is a channeling knowledge means so that learning becomes more lively, more maximal and efficient (Hartini et al., 2017; Maryanti \& Kurniawan, 2018; Praditya, 2019). Therefore, it is necessary to have a digital technology-based learning media that has the role to improve the student's information literacy skills.

The development of learning media on Civics subjects needs to be solved in order to overcome limitations in learning (Prameswari, 2018; Sunarti et al., 2016). However, there's just a number of civic education learning media practice critical thinking skills. In fact, the media is an instrumental input supporting learning changes. Focused on the learning media development based on Android technology. The android-based learning media development for civic education subjects is very important to develop because of very efficient, no longer using blackboards or context books, yet has switched to an alternative system that can support the learning process and change the student's mindset. So that, this media will support the e-learning based learning creation that supports environmental preservation activities. Therefore, civic education needs to develop learning that is not only on the memorization system of the material, but also trains students' information literacy skills using e-learning media that are environmentally friendly and easy to use. One of them is linking learning media with local wisdom in Indonesia.

Aside from being a teaching media, education is also promoting Indonesia local wisdom (Khusniati et al., 2017; Meliono, 2011; Parmin et al., 2015; Suastra, 2010). Basically, the relevant local wisdom study is planned and becomes a connection of traditional knowledge with modern knowledge (Khusniati et al., 2017; Setiawan et al., 2017). Modern knowledge at this time is information knowledge (information literacy) about various presentday insights. Local wisdom is a cultural element and a positive symbol to be explored and studied in order to be the national identity foundation in maintaining environmental balance and globalization challenges (Khusniati et al., 2017; Parmin et al., 2015; Setiawan et al., 2017; Uge et al., 2019). However, along with increasingly modern and practical times development, people instead to choose foreign cultures and instead reduce the public awareness attitude of local wisdom importance as a nation identity (Bauto, 2013; Gularso et al., 2019). In fact, there are many elements of Javanese culture that are diverse and must be preserved, such as language and knowledge systems, religion/belief, livelihood systems, Arts, social organizations, Living System Equipment \& Technology, and values/ norms and customs local residents.

Research on literacy learning media has been conducted by (Dafit et al., 2019) stated that literacy corner program gives an influence on students' reading interest viewed from aspects of enthusiasm in reading books, awareness as a student to read books, awareness of the importance of books, interest in reading books, interest in reading books, utilizing time to read books, choosing reading books, desires looking for sources to read books. Research conducted by (Andhini et al., 2020) stated that the results of this study is the design of the lite room application (Literacy Room), which is a reading room provider application intended for school students for elementary, junior high, and high school equivalent and this application has four main features, namely the reading room, diary room, show of works, and windows of the world to facilitate students in accessing reading material, increase the ability to titrate, and increase knowledge. The difference between this study and previous research is that this study includes art as part of improving student information literacy and learning such as 
e-learning media that is demanded by the modern era in the school environment to support appropriate learning.

Based on this statement, it is known that the connection between the use of media by following the demands of the $21^{\text {st }}$ century on civic education learning is important and needs to be done to know the students' information literacy abilities. Therefore, to find out the real conditions, research is needed to find out how the results of the use of the gejog lesung based e-learning media on the material on the 1945 constitution. This study aims to analyze students' information literacy ability enhancement using android (gejog lesung) on the 1945 constitution.

\section{Method}

Research methodology is quasi-exsperimental study with one grup pretest posttest design. The learning process use Gejog Lesung android based civic e-learning media. This media is used to train the high school students' information literation and introduce one of the culture of the Indonesian people in Yogyakarta, Gejog lesung. This research was conducted in Sleman, Regency, Yogyakarta, Indonesia. Used 35 students as subjects. They are first grade of senior high school 01 Ngaglik, Sleman, Yogyakarta. The test used in this study aims to collect data consisting of pretest and posttest information literacy questions with HOTs criteria for information literacy skills.

Validation is done by two expert judgements. There are Initial Data Analysis and Hypothesis testing. Initial Data Analysis has done with Normality test. Normality test is used to see the of student values distribution in class, whether the pretest and posttest results are normally distributed or not. To conduct a normality test, the SPSS application is used; and Hypothesis testing test is used to test the hypotheses that have been submitted. Hypothesis testing is done by t-test to determine the different power of student's information literacy skills on the 1945 Constitution. There is pretest and posttest are given after that to map the Gejog Lesung android based civic e-learning media, prior to implementation of students' information literacy skills engagement. The t-test is using the SPSS application. Decision making for hypothesis using acceptance or rejection criteria of naught hypothesis $\left(\mathrm{H}_{0}\right)$ at a significance level of $5 \%$ is if $t_{\text {test }}>t$ table then the naught hypothesis $\left(\mathrm{H}_{0}\right)$ rejected or alternative hypothesis $\left(\mathrm{H}_{\mathrm{a}}\right)$ accepted, yet if $t_{\text {test }}<t_{\text {tabel }}$ is naught hypothesis $\left(\mathrm{H}_{0}\right)$ accepted or alternative hypothesis $\left(H_{a}\right)$ rejected.

\section{Result and Discussion}

Table 1 present research data on information literacy ability scores based on the pretest posttest results.

Table 1. Data on information literacy ability

\begin{tabular}{ccc}
\hline \multirow{2}{*}{ Data source } & \multicolumn{2}{c}{ Class } \\
\cline { 2 - 3 } & Pretest & Posttest \\
\hline Min & 20 & 50 \\
Max & 90 & 100 \\
Mean & 65,14 & 85,00 \\
Median & 70,00 & 85,00 \\
SD & 16,868 & 13,617 \\
\hline
\end{tabular}

Table 1, the study results show the information literacy ability average scores that differ greatly. The average score for students' pretest information literacy skills is 20 , while the test results after treatment with gejog lesung android based civic e-learning has an average information literacy ability for posttest is 50 . Score higher than that of classes that do not were given gejog lesung android based civic e-learning or conventional learning. Students' pretest and posttest normality can be seen in Table 2. 
Table 2. Students' Pretest and Post Test Normality

\begin{tabular}{lcccc}
\hline & Class & \multicolumn{3}{c}{ Shapiro-Wilk } \\
\cline { 2 - 4 } & Statistic & Df & Sig. \\
\hline Pretest & 0,930 & 35 & 0,027 \\
Posttest & 0,913 & 35 & 0,009 \\
\hline
\end{tabular}

Table 2 present both pretest and posttest value have a significance value above 0.05 so that the data can be caused normally distributed. T-test results of Students' literacy information ability N-Gain Data can be seen in Table 3.

Table 3. T-Test Results of Students' literacy information ability N-Gain Data

\begin{tabular}{|c|c|c|c|c|c|}
\hline \multirow{2}{*}{$\begin{array}{l}\text { Learners' Critical } \\
\text { Thinking Skills }\end{array}$} & \multicolumn{2}{|c|}{$\begin{array}{l}\text { Levene's Test for } \\
\text { Equality of Variances }\end{array}$} & \multicolumn{3}{|c|}{ t-test for Equality of Means } \\
\hline & $\mathbf{F}$ & Sig. & $\mathbf{t}$ & df & $\begin{array}{l}\text { Sig. }(2 \\
- \text { tailed })\end{array}$ \\
\hline $\begin{array}{ll}\text { Equal } & \text { variances } \\
\text { assumed } & \end{array}$ & 1,659 & 2,202 & $-5,107$ & 65 & 0,000 \\
\hline $\begin{array}{l}\text { Equal variances not } \\
\text { assumed }\end{array}$ & & & $-5,107$ & 65,104 & 0,000 \\
\hline
\end{tabular}

Table 3 the t-test is carried out using the assumption that both variances are equal (equal variances assumed). The value for the same gain variance is $-5,107$ with a degree of freedom 65 and a significance value of 0,000 . Based on the table, the value of $t$ for $\mathrm{df}=$ 65 is 1.997 . From the signification significance level of $1.997<0.05$, it can be concluded that $\mathrm{H}_{0}$ is rejected $\mathrm{H}_{\mathrm{a}}$ is accepted. Since $\mathrm{H}_{0}$ was rejected and $\mathrm{Ha}$ was accepted, it can be concluded that there was an influence of the android (Gejog Lesung) based civic e-learning on the information literacy ability first grade students' on senior high school Ngaglik 1, Yogyakarta, on the 1945 constitution. N-gain data can be seen in Table 4.

Table 4. N-gain data

\begin{tabular}{ccc}
\hline Number of Samples & Average N-gain & Classification \\
\hline 35 & 1,4 & High \\
\hline
\end{tabular}

Table 4 shows that the pretest and posttest results on 35 students experienced an increase in information literacy ability on the 1945 Constitution. The results showed an n-gain of 1.4 with a high category. This product is a civic education learning media that is used on the 1945 constitution in the state governance framework. This learning media is applied on android platform-based mobile phones to support the skills of students in the $21^{\text {st }}$ century and in accordance with the educational the 4.0 revolution era needs. This media was developed through the iSping application. Learning media is a media that is creative, innovative, and educative so as to make learning activities more conducive, interactive and fun with evaluation equipped in accordance with the HOTs indicators of information literacy abilities. In addition, this media is also suitable for classes used that are indeed considered by teachers to be difficult to manage and make noise, because with this media, students become calmer and can participate in learning conducive. Therefore, this product can improve the literacy information ability of first grade students on senior high school Ngaglik 1, 
Yogyakarta students on the 1945 constitution in the practice framework of implementing state government effectively and attractively for use in teaching and learning activities because it uses Android technology from smartphones.

Based engaging students' information literacy ability on the 1945 constitution toward android (gejog lesung) based e-learning media as a whole has n-gain student's information literacy skills on the 1945 constitution in the state government practice framework values of 1,4 in high category represented in Figure 1.

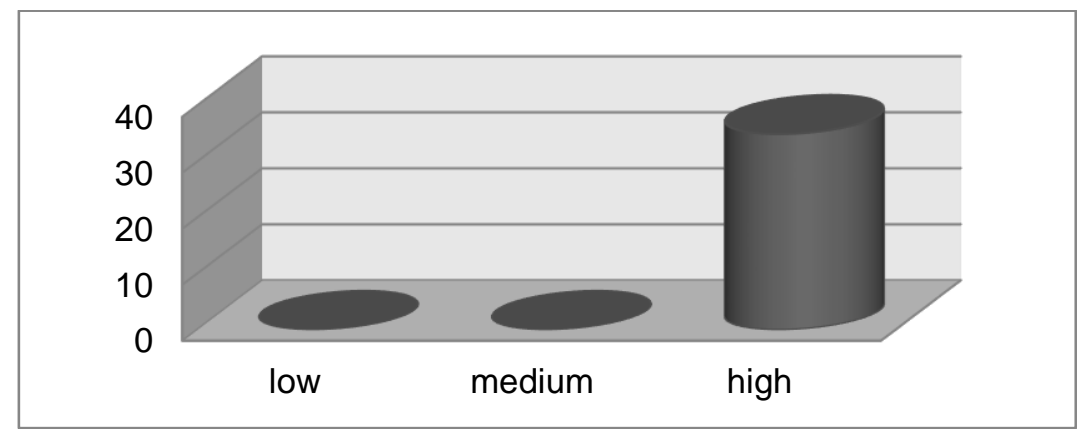

Figure 1. N-Gain information literacy skills n-gain chart

Figure 1 concluded that enggaging students' information literacy ability on the 1945 constitution toward android (gejog lesung) based e-learning media as a whole has n-gain for students' information literacy ability on the 1945 constitution in the high category.

The android (Gejog Lesung) is one part of many physical arts types that contain many educational values, local wisdom, and are very relevant to life today, especially the values contained in the opening of the 1945 constitution and Pancasila. Educational values contained in the mortar gejog include, religious values, ethical values and politeness, responsibility, mutual cooperation, nationalism, national unity and unity, values of social justice and deliberation, and personality. The aforementioned core values are in line with $\mathrm{Ki}$ Hajar Dewantara's thoughts which state that physical arts, like the (gejog lesung) are not only as sports media, but also as a media of education. Values Interpretation of the gejog lesung various movement meaning becomes one of the ways to understand the moral and character education values contained in the (gejog lesung). The intended educational value aims to help humans to be able to understand, realize, internalize, and practice the values of goodness so that they can place them well in everyday life. Educational values contained in the (gejog lesung) that are relevant to the values contained in the opening of 1945 constitution to be understood and studied include: Religious values; this value can be pointed out in the variety of nutu movements performed during the performance. Following is the description of the nutu movement in Figure 2.

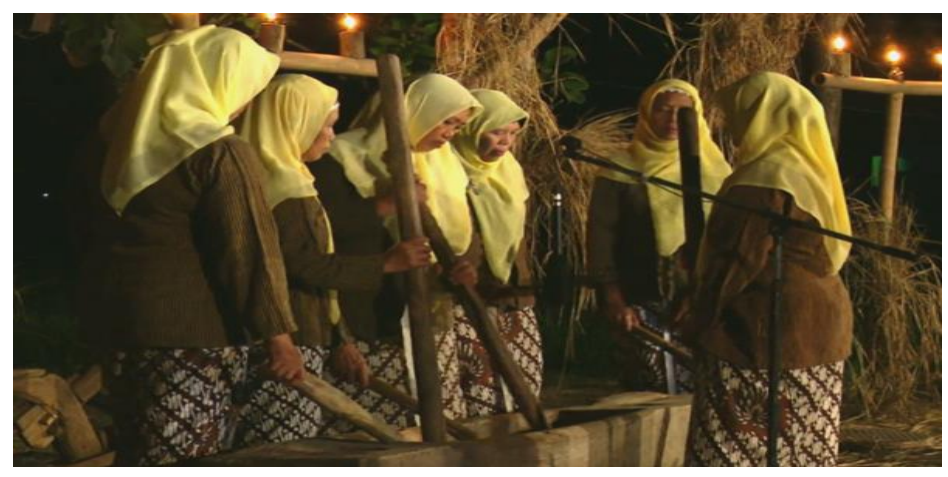

Figure 2. Nutu movement on Gejog Lesung 
Figure 2 concluded the nutu movement meaning is in accordance with the meaning contained in the preamble to the 1945 constitution "for the blessing of the grace of God Almighty and by being encouraged by noble desires, so that national life can be free". This shows that the nutu movement in the Gejog Lesung can be interpreted as happiness and gratitude form for nature's blessings in the abundant and quality rice harvest form of given by God Almighty to humankind, especially farmers. This can also be interpreted as evidence that humans as weak creatures should always ask, ask, and thank God for all the blessings and blessings given in life.

The politeness value is an interpretation of the variety movements Nyingset Serong. In ancient times, this movement was interpreted as an effort to pay tribute to the King and the invited guests present. Nyingset Serong is a positive attitude form, during the movement, dance is also accompanied by songs and a little theater about every day that can be interpreted as human beings belonging to social beings are required to respect one another. The Nyingset Serong movement meaning is also in accordance with the meaning contained in the preamble to the 1945 constitution "just and civilized humanity". It's mean that the Nyingset Serong motion range means that humans must respect and protect one another. Humans must have a humble attitude in saying, then in daily life should, humans can be mutual tolerance, protect and respect each other, or fellow living creatures. Engaging students' information literacy ability on the 1945 Constitution Toward Android (Gejog lesung) based on e-Learning media is an innovative, creative and fun media. Using Gejog lesung media will mak students more independent in learning.

The responsibility value is an interpretation of the variety of movements of Nekuk Siku Mlumah Asto. Nekuk Siku in Indonesian means to bend the elbow, yet if it is understood deeper, then bending the elbow can be explicitly interpreted as an attempt to roll up a sleeve to help or do something harder and harder. While the meaning of Mlumah Asto can be interpreted using the hands. The overall meaning of the Nekuk Siku Mlumah Asto movement can be interpreted by human efforts to take responsibility in caring for, maintaining, preserving and improving themselves. Then for the connection between the meaning of the Nekuk Siku Mlumah Asto movement and the preamble of the 1945 Constitution in the fifth precepts "realizing a social justice for all Indonesian people". The range of movements of Nekuk Siku Mlumah Asto means that every human being must be able to take responsibility for what he has chosen before. The responsibilities that have been chosen are carried out to create harmony between people by prioritizing common interests above personal interests based on the noble life philosophy in the national and state order. Engaging students' information literacy ability on the 1945 Constitution Toward Android (Gejog dimples) based on E-Learning Media is learning based on local wisdom in Indonesia. this media makes learning better and in line with the demands of the $21^{\text {st }}$ century to leave the culture of Indonesian.

Next is the ethical value. This value is an interpretation of the movement's variety of Kothekan and Nginteri. Kothekan movement in Indonesian can be interpreted by beating or hitting using a pestle (a special stick to pound rice) regularly. While the Nginteri movement means accompanying or matching the activities of the Gejog Lesung. The message that can be taken from the movement of pounding or pounding mortar can be interpreted with the attitude of someone wanting to take or decide an action, then it must be thought carefully and carefully. Therefore, when humans want to make an important decision, it is necessary to be guided by religious norms and politeness ethics in order to avoid bad attitudes and regrets in the future. The meaning of the Kothekan and Nginteri movements is also in accordance with the meaning contained in the preamble of the 1945 constitution and Pancasila in the $4^{\text {th }}$ precepts, "the money populace is led by wisdom in the deliberation of representation". This means that the movements variety of kothekan and Nginteri means that every human being has the responsibility and ethics of holding consultations to realize a socially just State.

Utilization of information technology on learning systems in schools has transformed conventional learning systems into modern patterns that utilize sophisticated internet networks. Learning by using this system allows students to access media and learning activities without being limited to time and space. Therefore, the teacher as a learning 
milestone must be able to control the progress, starting from the planning, implementation, assignment, monitoring of learning, and evaluation in accordance with the times. The form of writing used must also vary. Not only with paper, but also can be developed with quizzes that can enable teachers to assess the realm of students' knowledge and abilities in learning. This is in line with research conducted by (Rijal \& Sofiarini, 2019) stated that e-learning has been practical both in terms of implementation, convenience, and time required with an average value of $92.5 \%$ and e-learning has also been effective in terms of student learning activities and outcomes with an average value of $81.2 \%$ activity and learning outcomes with a mastery level of $87.5 \%$. Research conducted by (Yulita et al., 2018) stated that the developed e-learning device is declared as feasible learning media that can help delivering the materials and the structured tasks for students. The implementation of learning with the e-learning system can help learning that no longer has to be face-to-face, can be accessed anytime and anywhere (Getuno et al., 2015; Muliyati et al., 2019; Nisa, Choirun, 2018). Therefore, it is necessary to plan systematically with the availability of innovative supporting media, especially on learning material for civic education learning.

Civic education is learning that is moral cultivation in the younger generation. Civic education shapes the skills of citizens who have the knowledge, skills and values needed to actively participate in the development of the global world in the $21^{\text {st }}$ century. In reality, the learning of civic education in schools has not been designed by accommodating students to build information literacy skills as a whole using interesting and fun learning media, so the learning process is only focused on memorizing, becoming monotonous, and boring. Therefore, the selection of instructional media that can train students' information literacy ability in civic education subjects must be fulfilled with the development of the media of the gejog lesung based on e-learning media.

Pancasila values and the 1945 Constitution are relevant to the gejog lesung which focuses on various movements and can be used as a media for learning technology-based citizenship education in accordance with the industrial revolution 4.0. Android platform-based technology is a suitable media development option for students to develop in Yogyakarta. Gejog lesung based on e-learning media is applied to civic education learning about the implementation of the state government to train students' information literacy skills in accordance with the demands of the $21^{\text {st }}$ century can be seen in Figure 3 .

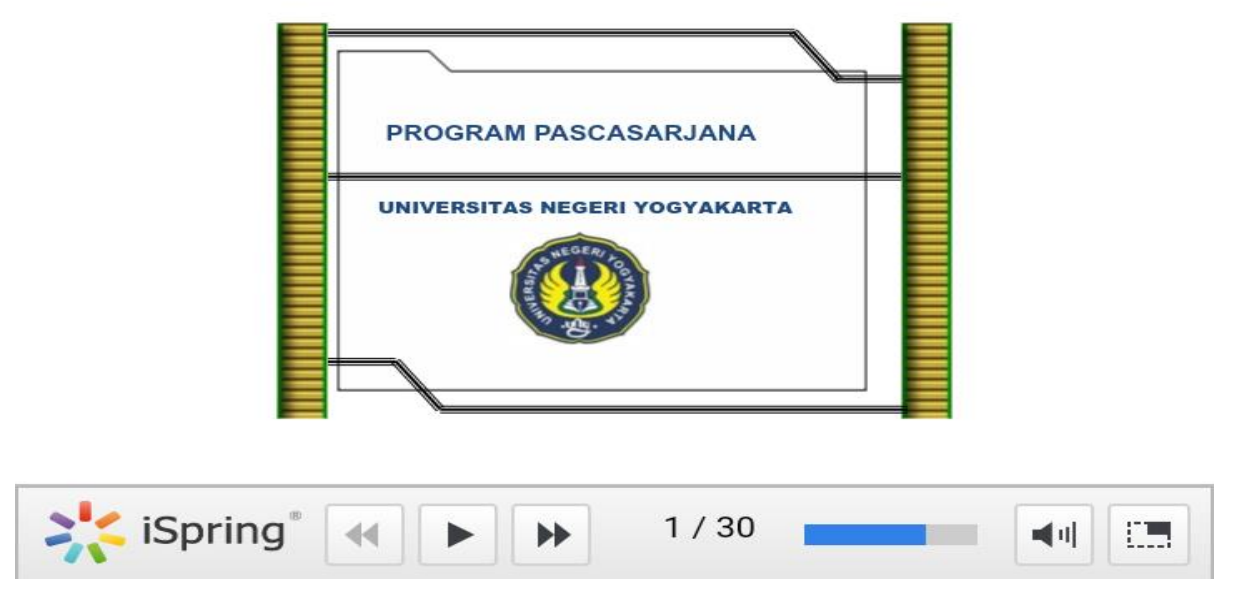

Figure 3. Android civic e-learning media

On the other hand, innovative learning media that practice $21^{\text {st }}$ century skills are integrated with 4.0 technology are significant to be a tool to promote the preservation of the archipelago culture to the younger generation. In addition, the development of civic education media based on indigenous knowledge at other age ranges can also be an interesting future research. Qualitative studies on the effect of using original knowledge about civic education learning will be a valuable research breakthrough going forward. 
Research on literacy learning media has been conducted by (Dafit et al., 2019) stated that literacy corner program gives an influence on students' reading interest viewed from aspects of enthusiasm in reading books, awareness as a student to read books, awareness of the importance of books, interest in reading books, interest in reading books, utilizing time to read books, choosing reading books, desires looking for sources to read books. Research conducted by (Andhini et al., 2020) stated that the results of this study is the design of the lite room application (Literacy Room), which is a reading room provider application intended for school students for elementary, junior high, and high school equivalent and this application has four main features, namely the reading room, diary room, show of works, and windows of the world to facilitate students in accessing reading material, increase the ability to titrate, and increase knowledge.

\section{Conclusion and Suggestion}

Based on the finding and discussion, it can be concluded that engaging students' information literacy ability on the 1945 constitution toward android (gejog lesung) based elearning media has a great effect on improving students' information literacy ability of first grader at senior high school 1 Ngaglik on the 1945 constitution value and engaging students' information literacy ability on the 1945 cnstitution toward android (gejog lesung) based elearning media is able to improve student information literacy ability in first grades at senior high school Ngaglik on the 1945 constitution value is in high category.

\section{References}

Alam, G. M., Forhad, A. R., \& Ismail, I. A. (2020). Can education as an 'International Commodity' be the backbone or cane of a nation in the era of fourth industrial revolution? - A Comparative study. Technological Forecasting and Social Change, 159(May). https://doi.org/10.1016/j.techfore.2020.120184

Andhini, A. D., Cahyati, J. N., \& Huda, M. (2020). Mobile-Based Literoom Application To Increase School Literation Ariyani. AL-ISHLAH: Jurnal Pendidikan, 12(1), 31-51. https://doi.org/10.35445/alishlah.v12i1.164

Bauto, L. M. (2013). Socio-Cultural Values As Community Local Wisdom Katoba Muna in the Development of Learning Materials Social Studies and History. Historia: Jurnal Pendidik Dan Peneliti Sejarah, 14(2). https://doi.org/10.17509/historia.v14i2.2027

Caruso, L. (2018). Digital innovation and the fourth industrial revolution: epochal social changes? Al and Society, 33(3), 379-392. https://doi.org/10.1007/s00146-017-0736-1

Dafit, F., Mustika, D., \& Melihayatri, N. (2019). Pengaruh Program Pojok Literasi Terhadap Minat Baca Mahasiswa Pgsd Fkip Uir. Jurnal Basicedu, 3(2), 117-130. https://doi.org/10.31004/basicedu.v4i1.307

Dianti, P. (2014). Integrasi Pendidikan Karakter Dalam Pembelajaran Pendidikan Kewarganegaraan Untuk Mengembangkan Karakter Siswa. Jurnal Pendidikan IImu Sosial, 23(1), 58-68. https://doi.org/10.17509/jpis.v23i1.2062

Dolničar, D., Boh Podgornik, B., Bartol, T., \& Šorgo, A. (2020). Added value of secondary school education toward development of information literacy of adolescents. Library and Information Science Research, 42(2). https://doi.org/10.1016/j.lisr.2020.101016

Geisinger, K. F. (2016). 21st Century Skills: What Are They and How Do We Assess Them? Applied Measurement in Education, 29(4), 245-249. https://doi.org/10.1080/08957347.2016.1209207

Getuno, D. M., Kiboss, J. K., Changeiywo, J., \& Ogola, L. B. (2015). Effects of an e-learning module on students ' attitudes in an electronics class. Journal of Education and Practice, 6(36).

Gularso, D., Sugito, S., \& Zamroni, Z. (2019). Kawruh pamomong: children education based on local wisdom in Yogyakarta. Cakrawala Pendidikan, 38(2), 343-355. https://doi.org/10.21831/cp.v38i2.21556 
Hartini, S., Misbah, Dewantara, D., Oktovian, R. A., \& Aisyah, N. (2017). Developing learning media using online prezi into materials about optical equipments. Jurnal Pendidikan IPA Indonesia, 6(2), 313-317. https://doi.org/10.15294/jpii.v6i2.10102

Hong, J., Thakuriah, P. (Vonu), Mason, P., \& Lido, C. (2020). The role of numeracy and financial literacy skills in the relationship between information and communication technology use and travel behaviour. Travel Behaviour and Society, 21(August), 257264. https://doi.org/10.1016/j.tbs.2020.07.007

Huynh, T. L. D., Hille, E., \& Nasir, M. A. (2020). Diversification in the age of the 4th industrial revolution: The role of artificial intelligence, green bonds and cryptocurrencies. Technological Forecasting and Social Change, 159(April). https://doi.org/10.1016/j.techfore.2020.120188

Insyasiska, D., Zubaidah, S., \& Susilo, H. (2015). Pengaruh Project Based Learning Terhadap Motivasi Belajar, Kreativitas, Kemampuan Berpikir Kritis, Dan Kemampuan Kognitif Siswa Pada Pembelajaran Biologi. Jurnal Pendidikan Biologi, 7(1). http://dx.doi.org/10.17977/um052v7i1p9-21

Khusniati, M., Parmin, \& Sudarmin. (2017). Local wisdom-based science learning model through reconstruction of indigenous science to improve student's conservationist character. Journal of Turkish Science Education, 14(3), 16-23. https://doi.org/10.12973/tused.10202a

Listiana, H. (2018). Penerapan Model "Baca, Tulis, Dan Bagi" Dalam Penguatan Literasi Pada Mahasiswa Pendidikan Guru Madrasah Ibtidaiyah Stain Pamekasan. ELEMENTARY: Islamic Teacher Journal, 6(1), 143-169. https://doi.org/10.21043/elementary.v6i1.4220

Maryanti, S., \& Kurniawan, D. T. (2018). Pengembangan Media Pembelajaran Video Animasi Stop Motion Untuk Pembelajaran Biologi Dengan Aplikasi Picpac. Jurnal BIOEDUIN: Program Studi Pendidikan Biologi, 8(1), 26-33. https://doi.org/10.15575/bioeduin.v8i1.2922

Meliono, I. (2011). Understanding the Nusantara Thought and Local Wisdom as an Aspect of the Indonesian Education. TAWARIKH: International Journal for Historical Studies, 2(2), 221-234. https://doi.org/10.2121/tawarikh.v2i2.392

Muliyati, D., Herga Marizka, \& Bakri, F. (2019). E-Learning Using Wordpress on Physics Materials with The 5E Learning Cycle Strategy. Jurnal Penelitian \& Pengembangan Pendidikan Fisika, 5(2), 101-112. https://doi.org/10.21009/1.05205

Nisa, Choirun, L. (2018). Pengaruh Pembelajaran E-Learning Terhadap Hasil Belajar Mata Kuliah Statistics Mahasiswa Tadris Bahasa Inggris Fakultas Tarbiyah lain Walisongo. Jurnal Phenomenon, 2, 7-27. http://dx.doi.org/10.21580/phen.2012.2.1.416

Olszewski, B., \& Crompton, H. (2020). Educational technology conditions to support the development of digital age skills. Computers and Education, 150(February). https://doi.org/10.1016/j.compedu.2020.103849

Parmin, Sajidan, Ashadi, \& Sutikno. (2015). Skill of prospective teacher in integrating the concept of science with local wisdom model. Jurnal Pendidikan IPA Indonesia, 4(2), 120-126. https://doi.org/10.15294/jpii.v4i2.4179

Praditya, D. (2019). Multimedia Pembelajaran Dengan Evaluasi Instructional Game Matematika Siswa Kelas Vii Smplb-B Negeri 1 Buleleng. Jurnal Edutech Undiksha, 6(1), 66-76. http://dx.doi.org/10.23887/jeu.v6i1.20269

Prameswari, N. K. (2018). Peningkatan Dalam Penggunaan Media Ular Tangga Mata Kuliah Pendidikan PKn SD Materi Strategi Pembelajaran Pada Kemampuan Kognitif Mahasiswa Semester 2 STKIP Bina Insan Mandiri Surabaya. Jurnal Bidang Pendidikan Dasar (JBPD), 2(1). https://doi.org/10.21067/jbpd.v2i1.2188

Rijal, A., \& Sofiarini, A. (2019). Pengembangan E-Learning Mata Kuliah Pembelajaran 
Matematika Sd Berbasis Aplikasi Moodle Di Pgsd. Jurnal Basicedu, 3(4), 2071-2082. https://doi.org/10.31004/basicedu.v3i4.266

Rohmawati, E., Widodo, W., \& Agustini, R. (2018). Membangun Kemampuan Literasi Sains Siswa Melalui Pembelajaran Berkonteks Socio-Scientific Issues Berbantuan Media Weblog. Jurnal Penelitian Pendidikan IPA, 3(1), 8. http://dx.doi.org/10.26740/jppipa.v3n1.p8-14

Romero, M., Usart, M., \& Ott, M. (2015). Can serious games contribute to developing and sustaining 21st century skills? Games and Culture, 10(2), 148-177. https://doi.org/10.1177\%2F1555412014548919

Setiawan, B., Innatesari, D. K., Sabtiawan, W. B., \& Sudarmin, S. (2017). The development of local wisdom-based natural science module to improve science literation of students. Jurnal Pendidikan IPA Indonesia, 6(1), 49-54. https://doi.org/10.15294/jpii.v6i1.9595

Setiwan, D. (2013). Reorientasi tujuan utama pendidikan IPS dalam perspektif global. JUPIIS: Jurnal Pendidikan IImu-IImu Sosial, 5, 58-72. https://doi.org/10.24114/jupiis.v5i2.1115.g888

Siddiq, F., Gochyyev, P., \& Wilson, M. (2017). Learning in Digital Networks - ICT literacy: A novel assessment of students' 21st century skills. Computers and Education, 109, 11-37. https://doi.org/10.1016/j.compedu.2017.01.014

Suastra, I. W. (2010). Model Pembelajaran Sains Berbasis Budaya Lokal Untuk Mengembangkan Kompetensi Dasar Sains dan Nilai Kearifan Lokal di SMP. Jurnal Pendidikan Dan Pembelajaran, 43(2), 8-16. http://dx.doi.org/10.23887/jppundiksha.v43i1.1697

Sunarti, S., Rahmawati, S., \& Wardani, S. (2016). Pengembangan game petualangan "si bolang" sebagai media pembelajaran tematik untuk meningkatkan motivasi dan prestasi belajar siswa kelas V sekolah dasar. Jurnal Cakrawala Pendidikan, 1(1), 5868. https://doi.org/10.21831/cp.v1i1.8365

Suyono, S., Harsiati, T., \& Wulandari, I. S. (2017). Implementasi gerakan literasi sekolah pada pembelajaran tematik di sekolah dasar. Sekolah Dasar: Kajian Teori Dan Praktik Pendidikan, 26(2), 116-123. http://dx.doi.org/10.17977/um009v26i22017p116

Tsybulsky, D., \& Levin, I. (2019). Science teachers' worldviews in the age of the digital revolution: Structural and content analysis. Teaching and Teacher Education, 86. https://doi.org/10.1016/j.tate.2019.102921

Uge, S., Neolaka, A., \& Yasin, M. (2019). Development of social studies learning model based on local wisdom in improving students' knowledge and social attitude. International Journal of Instruction, 12(3), 375-388. https://doi.org/10.29333/iji.2019.12323a

van Laar, E., van Deursen, A. J. A. M., van Dijk, J. A. G. M., \& de Haan, J. (2017). The relation between 21 st-century skills and digital skills: A systematic literature review. Computers in Human Behavior, 72, 577-588. https://doi.org/10.1016/j.chb.2017.03.010

Yu, T. K., Lin, M. L., \& Liao, Y. K. (2017). Understanding factors influencing information communication technology adoption behavior: The moderators of information literacy and digital skills. Computers in Human Behavior, 71, 196-208. https://doi.org/10.1016/j.chb.2017.02.005

Yulita, A. R., Ambarwulan, D., \& Bakri, F. (2018). Pengembangan E-Learning Menggunakan Chamilo Untuk Membantu Proses Pembelajaran Fisika SMA Kelas X Semester II. Gravity: Jurnal Ilmiah Penelitian Dan Pembelajaran Fisika, 4(2), 15-25. https://doi.org/10.30870/gravity.v4i2.4029 